\title{
The Abstentionist Group in the Governor Election
}

\author{
Tatik Rohmawati \\ Government Sciences Department \\ FISIP Unikom \\ Bandung, Indonesia \\ tatik.rohmawati@email.unikom.ac.id
}

\begin{abstract}
The purpose of this research is to see and to know the abstentionist in the Governor Election. The election of the Governor is one of the real actions of the local democracy. Then, there are many abstentionists in every Governor election. This paper focuses on the abstentionist group in the Governor election. The researcher finds out that there are significant numbers of the abstentionist in the city area. This paper uses qualitative method, and the researcher takes part as the instrument of the research. The methods of collecting data in this research are observation, interview and documentation. The focus analysis of this paper shows that the abstentionist group in the city area is dominated by the intellectual people who have good education and strong idealism. The conclusion of this paper also shows us that the abstentionists in the city area are mostly coming from the universities' students and traders. The effect caused by the abstentionists is made low participation in the election. So that, to anticipate the abstentionists, the committee should maximize the election's campaign.
\end{abstract}

Keywords-Voters Behaviour, The Abstentionists, Governor's Election, Local Democracy.

\section{INTRODUCTION}

Local democracy is part of political subsystem in a country which influences the local government. Local democracy in Indonesia also represents a subsystem which gives the opportunity to develop the connection between the government and the local society.

One of the representation of the local democracy is the election of West Java Governor. The election holds on April 8th, 2008. That election is the first Direct Governor Election in West Java. The election date is concerned as a public day, but some people are misused that day. Actually, the existence of public day is to facilitate people to be free in order to go to the polling stations. In case, there are no more reason to do another activity. Generally, public day attracts people to go to outside the city or do another activity, so that this will create an opportunity to become abstain in the election. The raising of the abstentionist becomes the important issue in the electional process. According to the Educational Voters Network for Society-Jaringan Pendidikan Pemilih untuk Rakyat (JPPR), the General Election in some regions; 26 provinces of local leaders electional process started from 2005 to 2008 , surprisingly there are 13 general elections which are won by the abstentionists. They are general election of the local leader in North Sumatra, West Sumatra, Riau Island, Bangka Belitung Island, Bengkulu, Banten, West Java, Central
Java, East Java (round I), Central Kalimantan, South Kalimantan, South Sulawesi and Southeast Sulawesi [1]. It means that the total numbers of the Governor voters lose from the abstentionists.

This happens in the Local Leader Election in West Java, although Ahmad Heryawan-Dede Yusuf gain more votes than other candidates. Basically, they get 7.287.647 votes, but the abstain votes raise 9.130.594 votes

The Governor Election in West Java at 2008 is the first Direct General Election in West Java. People who fulfill the requirements as voters are able to give their votes. That election is participated by 27.972 .924 voters from 63.005 polling stations [1].

The Governor's Election process is held at April 8th, 2008. At that time, the electional day is a public day. So, people are able to give their votes. But in the reality, some of them do not give their votes [2]

According to Putu Suasta [3] there are two general abstentionists group. First, people become abstentionists as the representation of pragmatic's idea. Second, people chose abstain as their disappointment and rebellion's reactions.

The first group is usually done by businessman, professional people and others. By their rationality and independence mind, this group tends to apply 'loss and profit' to determine their decision. This could be understandable because their affiliations are not political parties whether good or bad, but 'a good environment' to support their business. They do not care about who will be the winner in the political party. They mostly think that the important thing is their business will not be disturbed and still well-developed.

The second group usually belongs to the activists in Lembaga Swadaya Masyarkat (LSM) / Non Profit Organization, intellectual people and other people who care about the destiny of the nation. This group usually becomes abtentionists when they lost their trust toward some political parties. Presenting their struggle, they prefer to do real with actions such as involving in LSM, striking and others activities.

According to Seymor Martin Lipset based on his research entitled Political Man: The Social Bases of Politics quoted by Miriam Budiardjo [4] he states that the variable which influences the perception of choosing a person is income, education, job, race, sex, age, place, situation, status and organization. 
Recently, there are no clear explanation about the reasons behind the abstentionist. Generally those reasons neither base on the assumsion nor good research.

The main reason of the writer chooses Coblong District to be case of this paper is: First, Coblong District is the high-abstentionist area. Second, Coblong District is located in the strategic place; city area. Third, there are many intelleqtual people (elite) whom can be seen from their educational background in this place. Fourth, Coblong is a disctrict that has enough potentiality and social status with various backgroud (job), then this place also has many mosques.

The above phenomena make writer to obtain the explanation 'in-depth' in case of the Governor Elcection's Process in Coblong District. Meanwhile, there are no studies which are discussed the reason behind the abstentionist yet.

\section{METHOD}

The writer uses one of the methods in qualitative research. That is case study. This research uses qualitative methodology by applying case study-method which is the form of empiric research. It should be investigating toward contemporary phenomena in the real life context, especially when it reaches the limitation between phenomena and unclearly proved context [5]

According to Schramm [5], the essence of case study is to try to shoot a particular decision or some decision, why the decision is being taken, how to apply it and what are the results [6]

The selected case is in Coblong District, because this place located in the city area. The abstentionists seem to stay in the city area.

This paper has the analysis unit. The analysis unit shows for who or whom the character is conducted (Soehartono, 2002: 29). Then, the analysis unit in this paper is the entity of the politics actors, which includes institution actor (The Chief of General Election Commission KPU West Java Province, The Chief of the Regional Election Commission KPUD Bandung and the Election Supervisory Committee Panwaslu Coblong District) and the abstentionists.

The technique of collecting data in this research includes observation, interview and documentation study. Based on the method which is used in this research, the data analysis is qualitative descriptive. Operationally, the technique of data analysis is done by several steps as stated by Miles and Huberman [7]

First, data reduction as the selectional processing, simplifying, classifying the general data from the results of the technical used and as the collecting data measurement in the field. Data reduction has been applied since the data collection. Reduction is applied step by step by resuming the data and exploring the diffuse theme.

Every selected datum is crossed by different informant in order to get good information in the interview and observational process. The information that sourced from the district organization's figures is crossed by the information from intellectual people in Coblong District and the Chief of General Election Commission in West Java and the Chief of General Commission Election in Bandung.

Second, data presentation is a valuable step to arrange the selected information to become statements. The qualitative data is presented by text form which spreads and separates based on the informants, and from the time which is collected those information. Then, data are classified based on the related problems toward the abstentionists group in Coblong District in General Election in West Java.

Third, making decision rellated to its reduction, interpreting and presenting the data which are done in the previous step. It is equaly process with the logic mechanism of inductive mind, then making decision will revenge with the specific cases to the general conclusion.

\section{RESULT}

The total voters in the Governor Election in West Java as reported by General Regional Election Commisison West Java, the Chief of the General Election Commission reports (KPU) the total numbers are 28 million people ${ }^{1}$. Hade (Ahmad Heryawan dan Dede Yusuf) raise 7,3 million voters (40,5\%), Aman (Agum Gumelar dan Nu'man Abdul Hakim) gain 6,2 million voters (34,5\%) and Da'I (Danny Setiawan dan Iwan Ridwan Sulandjana) get 4,5 billion voters $(25,0 \%)$ as seen in the Fig. 1 .

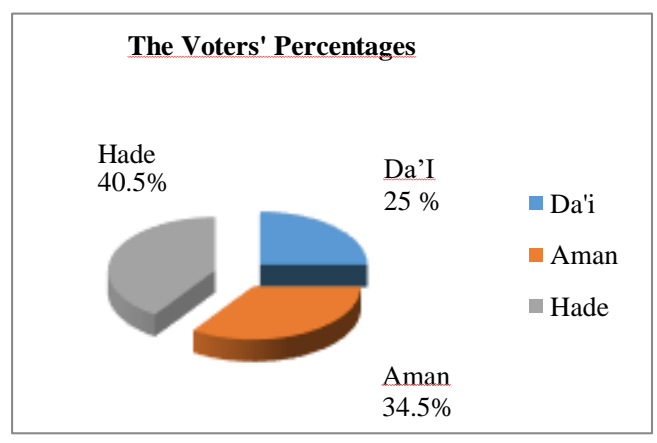

Fig.1. The Voters's Percentages Source: Hizbut Tahrir, 2008. Retrieved from http://hizbuttahrir.or.id/2008/05/01/fenomena-golput-dalam-pilkada. \{8 August 2009\} [8]

Fig. 1. shows the voters from each candidate. It is slightly difference from the candidate Hade and Aman. Then, Fig.1. shows the percentage of each candidate and the abstentionist.

1 The interview is hold in KPU office in West Java, Saturday, February $6^{\text {th }} 2010$ at 09.30 pm. 


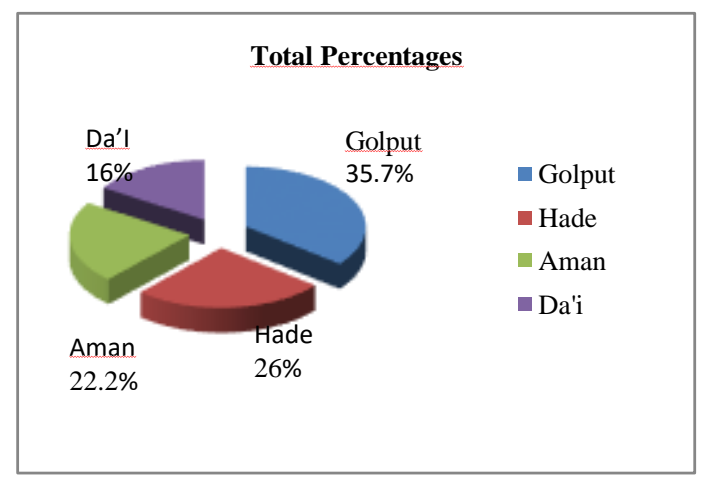

Fig.2 Total Percentages Source: Hizbut Tahrir, 2008. Retrieved from http://hizbuttahrir.or.id/2008/05/01/fenomena-golput-dalam-pilkada. $\{8$ August 2009\} [8]

Fig.2. shows that there are 10 million people who do not use their votes (abstentionists). If that percentages are calculated base on the total of the voters ( 28 million), so the abstentionists are $35,7 \%$, Hade $26 \%$, Aman $22,2 \%$ and Da'I $16 \%$.

Bandung voters are 1.574.332 voters and divided into 3.838 polling stations. Then most of voters in Coblong District are abstain. According to the interview with the chief of KPU West Java Province ${ }^{2}$, he declares that the abstentionists in West Java mostly are intellectual people who well educated. Based on the reality in the field, actually there are some educated people such as graduated from Under Graduate, Post Graduate and Research Scholar.

\section{TABLE I. CLASSIFICATION OF EDUCATION LEVEL IN COBLONG DISTRICT}

\begin{tabular}{|c|l|c|c|c|}
\hline \multirow{2}{*}{ No } & \multirow{2}{*}{$\begin{array}{l}\text { Education } \\
\text { Level }\end{array}$} & \multicolumn{3}{|c|}{ Totals } \\
\cline { 3 - 5 } & $\begin{array}{l}\text { Mneducated } \\
\text { (not going to } \\
\text { school) }\end{array}$ & 8515 & 8685 & 17200 \\
\hline 2 & $\begin{array}{l}\text { Under } \\
\text { Elementary } \\
\text { School }\end{array}$ & 2724 & 2511 & 5235 \\
\hline 3 & $\begin{array}{l}\text { Elementary } \\
\text { School } \\
\text { Graduates }\end{array}$ & 9087 & 8381 & 17468 \\
\hline 4 & $\begin{array}{l}\text { Junior High } \\
\text { School } \\
\text { Graduates }\end{array}$ & 7111 & 5568 & 12679 \\
\hline 5 & $\begin{array}{l}\text { Senior High } \\
\text { School } \\
\text { Graduates }\end{array}$ & 6749 & 6750 & 13499 \\
\hline 6 & Diploma & 3072 & 2658 & 5730 \\
\hline 7 & $\begin{array}{l}\text { Under } \\
\text { graduate }\end{array}$ & 3564 & 1839 & 5403 \\
\hline 8 & Post Graduate & 859 & 557 & 1416 \\
\hline 9 & $\begin{array}{l}\text { Research } \\
\text { Scholar and } \\
\text { others }\end{array}$ & 184 & 97 & 281 \\
\hline
\end{tabular}

Source: www.bandung.go.id, Pemerintahan Kecamatan Coblong. [March 2008] [9]

Table 1 shows that the education level in Coblong District is good enough. It can be seen from the totals of UG, PG students and Research Scholars.

The abstentionists mostly come from the citizen (people who live in the cities, not in the villages). The

2 Ibid 7 reason is, First, citizens usually reach high mobility so it migt disturb the citizenship administration. The citizenship data in Coblong District is not good enough, it can be seen from the way the government take data for the citizen, which are shown that died people still remain in the data. Second, citizens tend to criticize the government because they are more intellectual. Coblong District I located in the city centre that has significant potentiality. Citizens in Coblong District are dominantly getting accurate information about the local politics. It means that they may have high possibility to become abstentionists in this city. Basically, it can be seen from the number of educated people (university students) who have idealist thought.

Generally, the abstentionists are coming from various professions. They are university students, teachers, lecturers, traders and home assistants. Based on the fieldinterview with the Chief of PPK Coblong District ${ }^{3}$, the abstentionist group in Coblong District is from new comers, such as university students from government or non-government universities around Coblong District and some traders in Coblong District. The university students are educated, critical and idealist people. It menas that the university students have a certain consideration behalf on their absence in the election.

Then majority traders prefer to think their daily needs than give their votes for a certain candidate in the election. This information is gotten from interview with several university students and traders.

The educated students basically have critical thinking. Additionally, according to the students who have 'good education' 4 they believe that becoming abstentionists are one of their participation, because by not participate in the electional process is also their right, not their obligation". Furthermore, there are "few university students do not participate in the election because they do not get vote-card". This decreases the enthusiastic perception to participate in the election. The reason behind 'not getting vote-card', according to the writer, it is the side of the negligence and unprofessionality from the voters registration staff and from the verificational staff who do not review the Final Voters List. Another cause is because not listed as citizens in the local government office or he/she does not have ID card.

Otherwise, the Secretary of the Supervisory Committee of Governor Election in West $\mathrm{Java}^{5}$ states that the abstentionists in Coblong District come from the intellectual people such as university students 'who are very idealistic' and new-comers. New-comers here are some university students who live in the rent houses. At that time, the Election Day is declared as a public day, so that many university students see that

${ }^{3}$ The interview is held in the house of the Chief of PPL Coblong District at Thursday, $11^{\text {th }}$ February 2010 at 13.30 pm.

4 The interview is held in one of non-government universities on Monday, $15^{\text {th }}$ Februaary 2010 at $09.00 \mathrm{am}$.

5 The interview is held in the District office at Thrusday, $18^{\text {th }}$ February, 2010 at $11.10 \mathrm{pm}$. 
day as a good time to come back to their native homes. As a result, they might not participate in the election. This is behind the reason why they belong to the abstentionists group.

They believe that "becoming abstentionists are their right to do and it parts of the democracy" 6 . Democracy as the freedom to determine their right in the West Java Governor Election. Of course, their sides need to be valued and respected.

Based on the writer's point of view, the abstentionists are people who have political thought that become abstain is also their right. Then, the characteristics of the abstentionists group are:

1. They are not coming to the polling station. It means that they are intentionally not willing to participate in the election. This happens because they are busy and do not have time to go to their city and also they do not trust enough to the candidates.

2. They are coming to the polling station but they do not enter to the polling's booth. It means that they only fulfill the attendance list provided by the committee but they do not vote.

Then, for the abstentionists who go to the polling booth (using their right), they may classify to the valid ballot paper and invalid ballot paper. The invalid ballot paper can be caused:

1. The voters may make mistakes due to their lack of knowledge. Perhaps it happens when one mistakenly votes outside the ballot paper. It can cause the ballot paper becomes invalid and not calculated.

2. Intentionally vote on the candidate's name or vote more than one candidate.

3. Destroying the ballot paper

4. Entering to the polling booth but not intended to vote. Another word, it means that the voters give their ballot papers to the ballot box.

People who are permanently decided as voters but they are not willing to vote can be caused several cases. First, no one from the entire parties is their favour. Second, doing job at the election date. Third, General Election specifically does not have any benefits and only make benefit to a particular side.

Regarding to these issues on the Governor Election, the committee has to hold good socialization, arrangement and management. It could be politics education in how the important of being participate in the Governor Election behalf of the democracy implementation. For political parties, this case may be solved by media approach, dialogue or door to door's action.

Therefore, it is clear that the abstentionists group in Coblong District are coming from new-comers-

${ }^{6}$ The discussion is held in the teaching-learning activity which discussed the election of the Chief of Students' Senate of Unikom at Tuesday, $13^{\text {th }}$ December, $10.30 \mathrm{pm}$. universitry students and traders-. It can be seen that Coblong District is a strategic place to be traders' place. Otherwise, Coblong District is a significant enough region from several government or non-government universities, so that the totals of the university students who are living in the rent houses are high.

Another data which exposes the total numbers of the university students in Coblong District is on the table 3.4 (Coblong District's job).

According to the writer, the abstentionists group tend to be the second group; university students and intellectual people. The intellectual can be seen from the education level in Coblong District. From that table, it shows that most early voters are fresh graduated from Senior High School and others are UG, PG and Research Scholars.

\section{CONCLUSION}

The abstentionists group of Coblong District in West Java Governor Election 2013 mostly come from new-comers such as university students and traders. It is shown from the universities around this city. Meanwhile, many previous traders also remain in this city. The result of this research may be a suggestion to the government, especially to the General Election Commissions West Java Province. They need to socialize the election for some period (take more time) before the election day. So, it will motivate some voters to participate in the election (not become abstain)

\section{ACKNOWLEDGMENT}

Highest gratitude is addressed to BPKLN (Biro Perencanaan Kerjasama Luar Negeri) Departemen Pendidikan Nasional /Bureau of the Foreign Cooperation Planning of National Education Department for funding this research.

\section{REFERENCE}

[1] "Fokus Fenomena Golput," Media Poilitik dan Dakwah Al Wa'ie Membangun Kesadaran Umat, vol. IX, no. 97, 2008.

[2] "DPT dan TPS Pilgub Jabar 2008," J. Nas. dalam Bandung New, vol. I Maret, 2008.

[3] P. Suasta, "Golput, antara Peluang dan ancaman Bagi Parpol,' Polit. Obs. chief PIB party Bali, 2003.

[4] M. Budiardjo, Partisipasi dan Partai Politik, Sebuah Bunga Rampai. Jakarta: Yayasan Obor Indonesia, 1998.

[5] R. Yin, Case Study Research: Design and Method, second edition, Applied Social Research Methods Series, Volume 5. London: Sage Publications, 1994.

[6] A. Salim, Teori dan Paradigma Penelitian Sosial: Pemikiran Norman K. Denzin \& Egon Guba dan Penerapannya. Yogyakarta: PT Tiara Wacana, 2001.

[7] A. M. Miles, Matthew dan Huberman, Analisis Data Kualitatif: Buku Sumber tentang Metode-metode Baru. Jaakarta, 1992.

[8] S. Lajnah, "Fenomena Golput Dalam Pilkada," HTI, 2008.

[9] "Pemerintahan Kecamatan Coblong," 2008 